\title{
Development and reproductive performance of Swiss mice in an enriched environment
}

\author{
Carvalho, AFU.*, Araújo, AJ., Farias, DF., Rocha-Bezerra, LCB. and Cavalheiro, MG. \\ Laboratório de Fisiologia Animal, Departamento de Biologia, Universidade Federal do Ceará - UFC, \\ Av. Mister Hull, s/n, Campus do Pici, CEP 60455-760, Fortaleza, CE, Brazil \\ *e-mail: aurano@ufc.br
}

Received July 31, 2007 - Accepted October 30, 2007 - Distributed February 28, 2009

(With 4 figures)

\begin{abstract}
The present study investigated the effects of environment enrichment on the development and reproductive performance of an outbred Swiss strain. Physical enrichment consisted of free access of animals to tubular devices of different shapes and sizes. The development evaluation was done by monitoring growth rate during 39 days, from weaning (21 days) to the onset of sexual maturity ( 60 days of age). Over five consecutive gestations (105 days), the following variables were monitored: litter size, number of animals born alive; number of pups alive at 12 hours and on days 4, 9, 12, 15 and 18; number of animals weaned per litter; average weight of litters on days 4, 9, 12, 15 and 18. The reproductive performance was then evaluated using the inclusion of these variables in the indices of gestation and birth, viability, lactation, survival success, mating success and production. The results showed that the environmental enrichment did not influence, in a significant way, the evaluated parameters. However, there is no reason to deprive the animals from an enriched environment where they can develop their natural instinctive behaviour and guarantee health and well-being.
\end{abstract}

Keywords: environmental enrichment, development, reproductive performance, mice.

\section{Desenvolvimento e performance reprodutiva de camundongos Swiss em ambiente enriquecido}

\begin{abstract}
Resumo
O presente estudo investigou efeitos do enriquecimento ambiental sobre o desenvolvimento e a performance reprodutiva de camundongos outbred da linhagem Swiss. O enriquecimento teve como base o livre acesso dos animais a dispositivos tubulares de tamanhos e formas diferentes. A avaliação do desenvolvimento a partir da taxa de crescimento decorreu por um período de 39 dias, desde o desmame (21 dias) até os 60 dias de vida (maturidade sexual). Durante cinco gestações consecutivas (105 dias), foram registradas as seguintes variáveis: média do tamanho da ninhada, número de animais nascidos vivos; número de filhotes vivos em 12 horas, e nos dias 4, 9, 12, 15 e 18; número de animais desmamados por ninhada; e a média do peso dos filhotes nos dias 4, 9, 12, 15 e 18. A performance reprodutiva foi então avaliada a partir da inclusão dessas variáveis nos índices de gestação e nascimento, viabilidade, lactação, sucesso de sobrevivência, sucesso de acasalamento e produção. Os resultados obtidos mostraram que o enriquecimento ambiental não influenciou significativamente no desenvolvimento e na performance reprodutiva de camundongos da linhagem Swiss para nenhum dos parâmetros avaliados. Contudo, não há motivo para privar os animais de um ambiente enriquecido onde possam desenvolver seu comportamento instintivo natural e, consequentemente, viver com saúde e bem-estar.
\end{abstract}

Palavras-chave: enriquecimento ambiental, desenvolvimento, performance reprodutiva, camundongo.

\section{Introduction}

Laboratory housing conditions can deprive animals of the possibility to perform a wide set of normal behaviour (van de Weerd et al., 1998). The lack of capacity of the animals on developing species specific behavior may cause signs of suffering such as abnormal behavior or pathology (Jensen and Toates, 1993).
Environmental enrichment itself changes the environment introducing materials or objects that are stimulants to the animals, allowing them to express more of their natural repertoire of behaviour (Manosevitz and Montemayor, 1972). The most promising method to improve the welfare of experimental animals in laboratories 
is to enrich the handling conditions (Broom and Johnson, 1993). In one way, companionship can work as a way of environmental enrichment. In particular, individuals of the same species can give social support in stressful situations, and numerous studies point to this factor as being a positive one to the health of animals in captivity, especially in social life (Gonyou, 1986; Huls et al., 1991; Sachser et al., 1998; von Holst, 1998). On the other hand, the aggressive behavior of male mice may increase when groups with more than 3 individuals are formed (van Loo et al., 2001). However, natural elements, nest materials, and/or additional space may facilitate the animal enrichment, again by letting these animals motivated to show positive behaviour (Sachses et al., 1998; van Loo et al., 2001; Marashi et al., 2003).

Many authors performing behaviour tests on the effects of environmental enrichment upon mice have demonstrated a distinctive effect compared to those observed on animals under standard conditions, such as improved locomotory and exploratory activity (Manosevitz, 1970; Manosevitz and Montemayor, 1972; Prior and Sachser, 1995), object exploration (Renner and Rosenzweig, 1986; Widman and Rosellini, 1990), learning ability (Boehm et al., 1996; Röttger et al., 2001), problemsolving behaviour (Forgays and Forgays, 1952; Hebb, 1947), and decreased anxiety (Prior and Sachser, 1995). However, some reports have pointed out the lack of studies that discuss the effects of the enrichment devices on the rising and survival of mice (Inglis et al., 2004).

This work aimed to evaluate the effects of environmental enrichment initially on growth rate from weaning (with 21 days of age) to sexual maturity (60 days of age) (Ufaw, 1986) and later on reproductive performance, which was assessed by estimating the indices of gestation and birth, viability, lactation (Iturrian and Fink, 1968), mating success, surviving success and production (Potgieter and Wilke, 1997). Physical enrichment consisted of free access of animals to tubular devices of different shapes and sizes.

\section{Material and Methods}

\subsection{Animals}

Male (12) and female (12) mice mice (Mus musculus Linnaeus, 1758) of Swiss strain were obtained from the Animal Facilities of the Federal University of Ceará.

\subsection{Growth rate}

Females and males were separated forming 4 groups of six animals each in such a way that six males and six females formed the enriched group and the other animals formed the non-enriched group. The treatment was begun at weaning at 21 days of age and ended at the onset of sexual maturity by 60 days of age.

The animals were housed by sex and grouped in 4 polypropylene cages $17.5 \times 27.5 \times 13 \mathrm{~cm}$ (Beiramar, Campinas, Brazil), being two non-enriched and two enriched. The grounds of the cages were covered with 2 to
$3 \mathrm{~cm}$ of pine shavings (Biotécnicas, São Paulo, Brazil). The amount of food (Guabi Nutrilabor, Campinas, Brazil) and water were available ad libitum, being switched weekly.

In addition, the enriched group had access in their microenvironment to tubes and connections of poly vinyl carbonate (PVC) of many shapes (Figure 1). The tubes and connections were changed weekly in a way that the animals would always face a newly shaped device (Figure 2). During this stage the weight of the animals, in both treatments, was monitored every 72 hours. The final weight gain was determined by the difference between the final and initial weight of the animals.

\subsection{Reproductive performance}

By the onset of sexual maturity, the animals were mated as monogamic couples avoiding consanguinity. Six couples were formed in non-enriched conditions and six in enriched conditions. One female of the nonenriched group died for unknown reasons and one female of the enriched group had problems after the first gestation which apparently led to sterility. There were, then, 5 couples in enriched conditions and 5 couples in non-enriched conditions at this stage of the experiment.

After mating, all 10 couples were housed separately in polypropylene cages $17.5 \times 27.5 \times 13.0 \mathrm{~cm}$ (Beiramar, Campinas, Brazil). The amount of food, pine shavings and water was standardized in $200 \mathrm{~g}, 45 \mathrm{~g}$ and $500 \mathrm{~mL}$, respec-
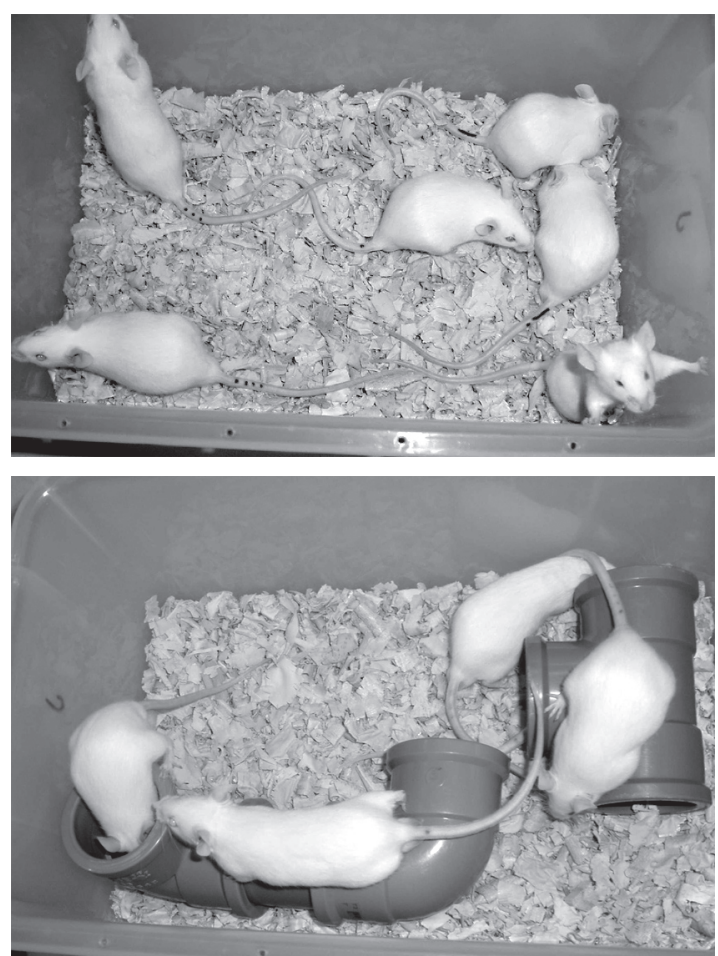

Figure 1. Non-enriched animal group and enriched group in their respective microenvironments. 

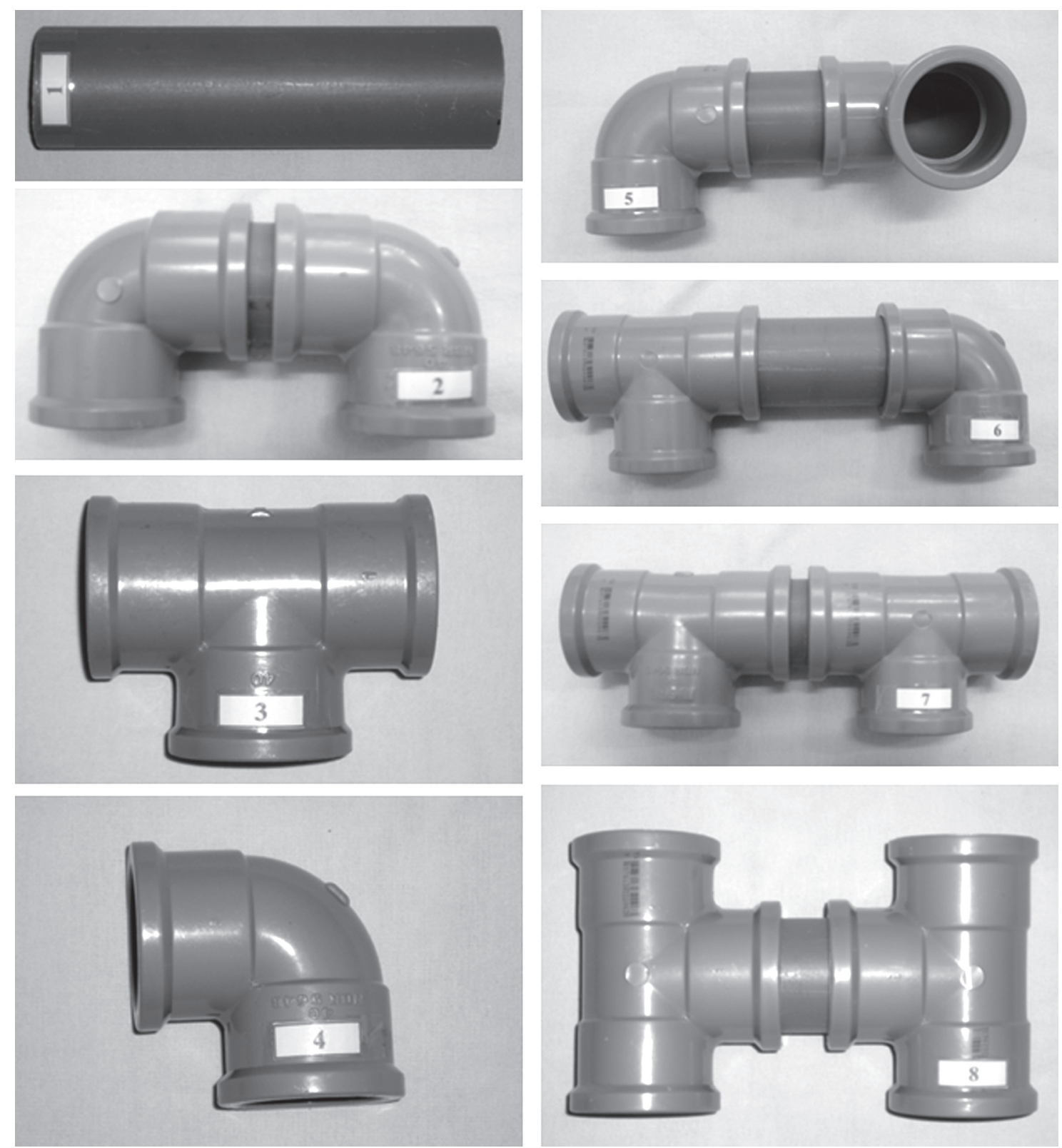

Figure 2. Tubular devices used as providers of environment enrichment.

tively, being swapped weekly. Five gestations were monitored (105 days) because after the sixth gestation there is a fertility compromise (Ufaw, 1986). Weaning occurred after 18 days of age to avoid contact between new-born pups and the previous hatch. During the experiment the following variables were monitored: litter size (number of animals born alive); number of pups alive in 12 hours and on days 4, 9, 12, 15 and 18; number of animals weaned per litter; average body weight of litters on days $4,9,12$, 15 and 18 and number of litters born per female.

Studies have demonstrated that, concerning deaths, the frequency is that $91 \%$ of those occur in the first
4 days post partum, and only $9 \%$ of deaths occur during the lactation period (Mirone et al., 1948). The number of pups alive on day 4 was, then, chosen as an indicator of pup viability (Potgieter and Wilke, 1997).

Since young mice start to consume solid food by day 12 , and milk yield reaches maximum levels on days 12 13 post partum, day 12 was used to determine the lactation index (Potgieter and Wilke, 1997).

The expectation for litter size was determined by counting the number of fetuses in 11 pregnant females (day 17 of pregnancy). These females were bred under standard conditions. 


\section{Statistical Analysis}

The statistical analysis of the animals' weight obtained every 72 hours and the final weight gain were evaluated with the software GraphPad InStat v. 3.06. The significance between the collected data from the enriched group (test) and those of the non-enriched group (control) was analyzed by $t$-Student simple comparison tests for parametric data and Mann-Whitney tests for non-parametric data. The level of confidence was $95 \%$ $(\alpha=0.05)$.

An estimation of the effects of the introduction of tubular shapes over the reproductive performance was calculated using the following formulas (Iturrian and Fink, 1968):

Gestation and birth $=\frac{\text { Average litter alive at birth } \mathrm{x} 100}{\text { Expected litter size }}$

Viability $=\frac{\text { Average litter alive on day } 4 \times 100}{\text { Average litter alive after birth }}$

Lactation $=\frac{\text { Average litter alive on day } 12 \times 100}{\text { Average litter alive on day } 4}$

The survival success, mating success and production were calculated according to Potgieter and Wilke (1997) as follows:

Survival Success $=\frac{\text { Average litter weaned } \mathrm{x} 100}{\text { Average litter born alive }}$

Mating Success $=\frac{\text { Number of litters born } \mathrm{x} 100}{* \text { Expected number of litters }}$

*The expected number of litters was determined by counting the gestations ( 5 females $\times 5$ gestations) and multiplying this value by the average litter size (11.27) obtained by counting the litters of 10 females sacrificed on day 16 of gestational period.

Production $=\frac{\text { Number of animals weaned } \mathrm{x} 100}{\text { Number of animals expected }}$

Data obtained from the calculated indices were submitted to statistical analysis with the software GraphPad InStat v. 3.06. Parametric and non-parametric simple index comparison tests obtained from the enriched and non-enriched groups were performed. For such comparisons, the t-Student test (parametric) evaluated the significance between the two treatments of the gestation and birth, lactation, survival success and mating success indices. The confidence level of the interferences was $95 \%(\alpha=0.05)$.

\section{Results}

\subsection{Growth rate}

There was no significant ( $\mathrm{p}>0.05 ; t$-Student test) difference between final body weight gain of males $(24.3 \pm 2.0 \mathrm{~g})$ and females $(19.6 \pm 2.4 \mathrm{~g})$ from the non-enriched group when compared to the males $(23.8 \pm 1.5 \mathrm{~g})$ and females $(17.5 \pm 2.4 \mathrm{~g})$ of the enriched group.
Figure 3 shows that the body weight gain observed every 72 hours in the males of the enriched environment and those in the non-enriched environment was significantly close to each other ( $\mathrm{p}>0.05 ; t$-Student test) and as a matter of fact it overlapped in many points. There was, however, a trend towards gaining more weight in the males of the enriched group and a trend towards greater weight gain in the females of non-enriched group, leading to a significant difference ( $\mathrm{p}<0.05 ; t$-Student test) on day 33 and in the interval of day 39 to 54 . On the other days there was no significant difference $(\mathrm{p}>0.05$; $t$-Student test) among the evaluated groups.

\subsection{Reproductive performance}

\subsubsection{Gestation and birth}

According to Table 1, the litter size of the animals in the enriched environment $(10.3 \pm 2.4)$ and those of the non-enriched environment $(10.8 \pm 1.5)$ was in all aspects equivalent to the expectancy for the litter size (11.3).

As shown in Table 2, the gestation and birth rates of animals in the non-enriched $(95.8 \pm 13.6 \%)$ and in the enriched group $(91.2 \pm 20.9 \%)$ were similar to each other ( $\mathrm{p}=0.2763$; Mann-Whitney test).
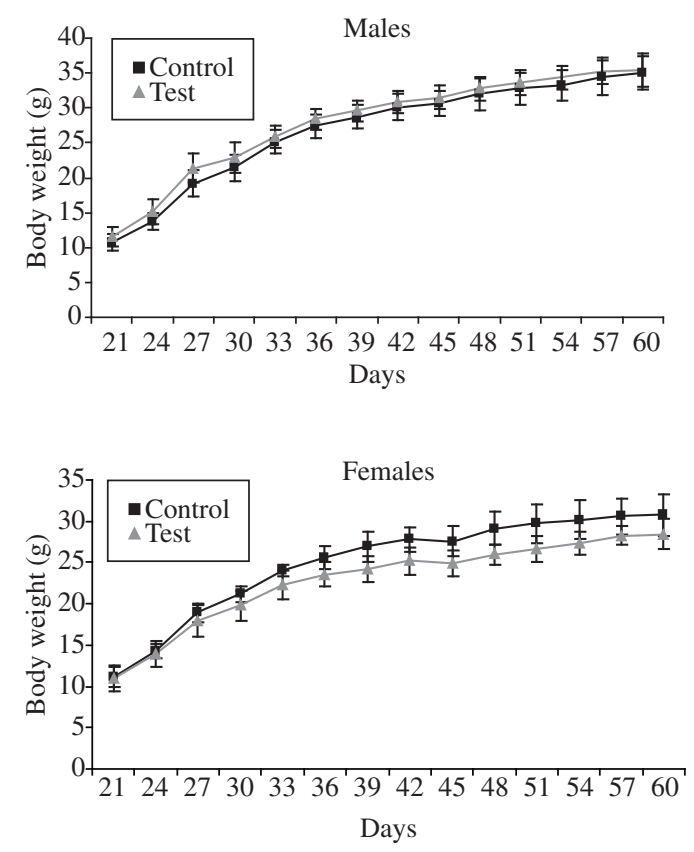

Figure 3. Body weight gain of males and females taken every 72 hours from non-enriched (control) and enriched group (test). There was no significant difference in body weight gain of males ( $p>0.05 ; t$-Student test) between the groups and a trend toward greater weight gain in the females of non-enriched group, leading to a significant difference ( $\mathrm{p}<0.05 ; t$-Student test) on day 33 and in the interval of day 39 to 54 . On the other days there was no significant difference ( $\mathrm{p}>0.05 ; t$-Student test) among the evaluated groups. 
Table 1. The effect of environmental enrichment upon the development and reproductive performance of mice from the Swiss strain.

\begin{tabular}{|c|c|c|c|c|c|c|c|c|c|c|}
\hline & \multicolumn{2}{|c|}{ Birth } & \multicolumn{2}{|c|}{ Viability } & & & & & & \\
\hline & $\mathrm{C}^{*}$ & $T^{* *}$ & C & $\mathbf{T}$ & & & & & & \\
\hline Number of pups & 270 & 257 & 267 & 256 & & & & & & \\
\hline Litter size average & 10.80 & 10.28 & 10.68 & 10,24 & & & & & & \\
\hline$(\mathrm{SD}) * * *$ & $(1.53)$ & $(2.35)$ & $(1.68)$ & $(2.28)$ & & & & & & \\
\hline Litter size expectation & 11.27 & 11.27 & 11.27 & 11.27 & & & & & & \\
\hline$(\mathrm{SD})^{*}$ & (1.27) & (1.27) & (1.27) & $(1.27)$ & & & & & & \\
\hline \multirow[t]{3}{*}{ Number of litters } & 11 & 11 & 11 & 11 & & & & & & \\
\hline & \multicolumn{2}{|c|}{ Day 4} & \multicolumn{2}{|c|}{ Day 9} & \multicolumn{2}{|c|}{ Day 12} & \multicolumn{2}{|c|}{ Day 15} & \multicolumn{2}{|c|}{ Day 18} \\
\hline & C & $\mathbf{T}$ & C & $\mathbf{T}$ & C & $\mathbf{T}$ & C & $\mathbf{T}$ & C & $\mathbf{T}$ \\
\hline Number of pups & 266 & 256 & 265 & 255 & 265 & 255 & 265 & 255 & 265 & 255 \\
\hline Litter size average & 10.64 & 10.24 & 10.6 & 10.2 & 10.6 & 10.2 & 10.6 & 10.2 & 10.6 & 10.2 \\
\hline$(\mathrm{SD}) * * *$ & $(1.60)$ & $(2.28)$ & $(1.58)$ & $(2.25)$ & $(1.58)$ & $(2.25)$ & $(1.58)$ & $(2.25)$ & (1.58) & $(2.25)$ \\
\hline Litter size expectation & 11.27 & 11.27 & 11.27 & 11.27 & 11.27 & 11.27 & 11.27 & 11.27 & 11.27 & 11.27 \\
\hline$(\mathrm{SD}) *$ & (1.27) & (1.27) & (1.27) & $(1.27)$ & (1.27) & $(1.27)$ & $(1.27)$ & $(1.27)$ & $(1.27)$ & (1.27) \\
\hline Number of litters & 11 & 11 & 11 & 11 & 11 & 11 & 11 & 11 & 11 & 11 \\
\hline
\end{tabular}

The couple that did not procreate during the study was omitted from the calculation of the litter average size. The number of pups born for each type of environment shows that there was no significant difference between these two environments. The litter size expectation was obtained using a standard environment. $* \mathrm{C}=$ control, mice in non-enriched environment; $* * \mathrm{~T}=$ test, mice in enriched group; $* * * \mathrm{SD}=$ Standard Deviation

Table 2. Comparison of developmental and reproductive parameters of Swiss strain mice housed in enriched (T) and nonenriched environment (C): Gestation and Birth (GN), Viability (V), Lactation (L), Survival Success (SS), Coupling Success (SA) and Production (P).

\begin{tabular}{llllccccccccc}
\hline & \multicolumn{2}{c}{ GN } & \multicolumn{1}{c}{$\mathbf{V}$} & \multicolumn{1}{c}{ L } & \multicolumn{2}{c}{ SS } & \multicolumn{1}{c}{ SA } & \multicolumn{1}{c}{ P } \\
\cline { 2 - 13 } & C & T & C & T & C & T & C & T & C & T & C & T \\
\hline Average \% & 95.8 & 91.2 & 99.7 & 100 & 99.7 & 99.7 & 98.1 & 99.4 & 95.8 & 91.2 & 94.1 & 90.5 \\
SD* & 13.6 & 20.9 & 1.4 & 0 & 1.7 & 1.7 & 4.0 & 2.1 & 13.6 & 20.9 & 14.0 & 20.0 \\
Number of litters & 25 & 25 & 25 & 25 & 25 & 25 & 25 & 25 & 25 & 25 & 25 & 25 \\
\hline
\end{tabular}

*SD = Standard Deviation.

\subsubsection{Viability}

As shown in Table 2, the viability of the animals in the non-enriched $(99.7 \pm 1.4 \%)$ and enriched group $(100 \pm 0.00 \%)$ was also similar to each other.

\subsubsection{Lactation}

No significant difference was observed ( $p=0.9917$; Mann-Whitney test) in the number of litters that reached 12 days of age between the groups, the lactation rate for both groups was $99.7 \pm 1.7 \%$ (Table 1 ).

There was no significant difference ( $\mathrm{p}>0.05$; $t$-Student test) between the control and test treatments concerning the body weight gain of the litters during the period between 4 and 18 days of age, although there was a trend towards greater weight gain in animals of the enriched group.

\subsection{Survival success}

There was no significant difference $(\mathrm{p}=0.4154$; Mann-Whitney test) of the survival success between the non-enriched and the enriched groups. Table 2 shows a survival success of $98.9 \pm 4.0 \%$ for the non-enriched group and $99.4 \pm 2.1 \%$ for the enriched group.

\subsection{Mating success}

The animals kept in both environments showed similar values of produced litters ( $\mathrm{p}=0.2763$; Mann-Whitney test). Table 2 shows a mating success of $95.8 \pm 13.6 \%$ in the non-enriched group and of $91.2 \pm 20.9 \%$ in the enriched group.

\subsection{Production}

As shown in Table 2, the production index of the non-enriched group was $94.1 \pm 14.0 \%$ and that of the 
enriched group was $90.5 \pm 20.0 \%$, indicating that both were equal to each other ( $\mathrm{p}=0.713 ; t$-Student test).

\section{Discussion}

\subsection{Rate of survival}

Although many authors have reported that environment enrichment influences the positive behavior of housed animals (van de Weerd et al., 1998; Jensen and Toates, 1993; Mench, 1994), this was not observed for the growth rate. It has been known that mice in superenriched housing conditions gain more weight than those kept under standard conditions (van de Weerd et al., 2004). Nevertheless in the present work, the results showed that the weight gain was similar, either for males or females in both groups. This result can be explained by the low diversification and/or inadequacy of the materials used as enrichment, since works have described materials with many different shapes such as ramps, ropes, stairs and little cages (Marashi et al., 2004). In addition to that, previous studies have shown that many physiological parameters susceptible to improvement by environmental enrichment are strongly influenced by the strain, group size and by the type and amount of enrichment devices used (Marashi et al., 2004; van de Weerd et al., 2004; Inglis et al., 2004).

The values of weight gain constitute the difference between the body weights at the end and at the beginning of the experiment. Thus it is not possible to show losses that occurred between 21 and 60 days of age. On the other hand, the weight gain measured every 72 hours revealed an increase of body mass in the females of both groups although body weight gain of females from the enriched group was inferior to those of the non-enriched group between 33 and 54 days of age. However, during the period between 55 and 60 days of age, the females of the enriched group gained weight more rapidly reaching the values of females of the non-enriched group. The period between 21 and 60 days of age is characterized by the transition of the juvenile to the adult stage (Ufaw, 1986) strongly influenced by hormonal activity. Therefore the association of the introduction of objects into the environment with a decrease in weight gain between 33 and 54 days of age is uncertain. As to males, the weight gain taken every 72 hours was regular and statistically similar to each other in the two groups ( $p>0.05)$.

Thus, it is clear that Swiss strain mice that have had access to many tubular shapes as promoting agents of enrichment did not gain weight significantly greater than those under standard conditions from weaning to sexual maturity.

\subsection{Reproductive performance}

The results concerning the gestation and birth indices met those described previously which have shown no difference among the non-enriched, the enriched and the super-enriched groups as to the number of litters born for the C57BL6 e CXCR3 -/- strains (Inglis et al., 2004).
Therefore the tubular devices used for environmental enrichment did not cause any ovulatory stimulation that could lead to a higher number of pups per litter. This supposition agrees with previous findings (Marashi et al., 2004), which have shown that there is no hormonal variation significantly different between enriched and nonenriched groups.

In this study, the mortality rate was extremely low up to the first four days of age, a fact that agrees with the results described by other workers (Iturrian and Fink, 1968). However, other reports (Mirone et al., 1948; Potgieter and Wilke, 1997) have shown higher mortality rates during this period. Potgieter and Wilke (1997) have found extreme variation in the mortality rate up to the fourth day of age in different strains varying from 20.7 to $69.6 \%$ under standard housing conditions (non-enriched), similar to the ones of the present work, especially in what concerns the bedding conditions. According to those authors, such variability and death incidence can be explained mainly by a different susceptibility of the strain to prenatal and postnatal cytotoxic effects caused by volatile hydro-carbons released from the pine shavings, leading to premature death of pups. The cause of death is less attributed to aggression or tendency for cannibalism shown by some strains. These peculiar behaviours are conditioned by genetic factors and stressing environmental conditions (Inglis et al., 2004).

The almost null mortality rate and consequent high viability found in this work, either for animals kept in enriched or non-enriched conditions, may be explained by a higher resistance to the cytotoxic effects of the pine shavings allied to a peculiar docility of the mice strain used.

As shown in Table 2, from birth to the fourth day of age, 4 deaths occurred in the non-enriched group and 2 deaths in the enriched group. The deaths must have been caused mainly by suffocation and/or by being stamped upon, and also, rarely, by cannibalism. However, being the Swiss strain extremely docile and kept in adequate conditions of nutrition and housing and, still, possibly resistant to the cytotoxic effects of pine shavings, the environmental enrichment as a promoter of pup viability would not be that efficient.

The lactation index deals with the ratio of surviving pups on day 4 , limit period to the viability index analysis, to surviving pups on day 12 which is considered the period in which the pups start to ingest solid food (Iturrian and Fink, 1968). The high and extremely similar index of lactation of both groups observed in the present study corresponds to those described in previous works with a low mortality rate from 4 to 12 days of age (Mirone et al., 1948). Mirone et al. (1948) and Potgieter and Wilke (1997) have stated that the rate of mortality during this period can reach values of around $9 \%$. Potgieter and Wilke (1997) have found a mortality rate of $1.4 \%$ and $9.5 \%$ in mice of the B6AKF1 and AKR strains, respectively. In mice of the C57BL6 strain, living under the same conditions, it was registered a mor- 
tality rate of $7.9 \%$ in the period from 9 to 12 days of age. This parameter can also reflect the resistance of the Swiss strain mice to the toxic effects of bedding material as mentioned above, but in no way can it be associated to the influence of environment enrichment. As shown in Table 2 and Figure 3 there is no significant difference $(p>0.05)$ between the enriched and non-enriched groups concerning the lactation rate. The two deaths that occurred during this period, one in the enriched and the other in the non-enriched group, were caused by suffocation and/or by being stamped upon.

The lactation index is, still, determinative in the good development of the pups, since a deficit on milk production would lead to inadequate weight gain and would raise death susceptibility by many causes.

Figure 4 shows that there was no difference between weight gain between pups kept in enriched and those in non-enriched environments during the lactation period. Therefore environment enrichment does not work as a promoting agent for lactation activity.

The survival rate of the pups until the $4^{\text {th }}$ day of age (viability index) and during the period between 5 and 12 days of age (index of lactation) was extremely elevated in both treatments (Table 2). Therefore the pups survived the period which is usually the one with the highest death incidence (Mirone et al., 1948; Potgieter and Wilke, 1997). As to the period between day 13 and weaning (18 days of life), this is characterized by low, and often null, mortality rate (Iturrian and Fink, 1968; Potgieter and Wilke, 1997) which agrees with the results found in the present work (Table 2). Due to the high index of lactation and viability in both groups, the success survival (from day 13 to 18 of life) was also high in both groups $(\mathrm{p}<0.05)$.

Inglis et al. (2004) have evidenced the positive influence of environment enrichment over the survival of weaned pups of the CXCR3-/- strain. However, any such influence on the same parameter in mice of the C57BL/6 strain has not been observed. This leads to the belief that the effect of environmental enrichment over the number of weaned pups is a factor that depends on the strain.

By comparing the average size of the litter born (mating success) to the litter size expectation, one can

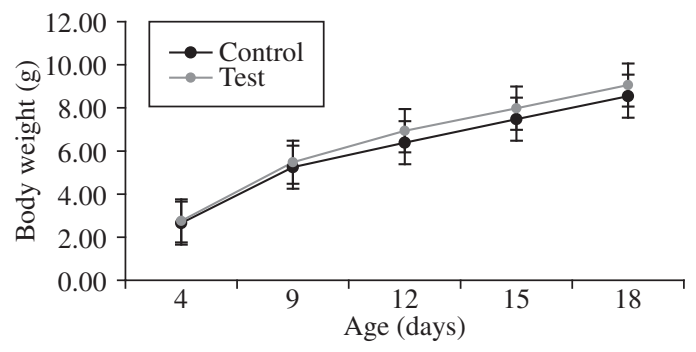

Figure 4. Comparison between body weight gain of growing Swiss mice kept on enriched (test) and non-enriched environment (control). There was no significant difference $(p>0.05)$ between group. observe that there is no significant difference between these values. The data taken from the analysis of this parameter were still similar in both groups, strengthening the idea that the environmental enrichment promoted by tubular objects did not contribute to the improvement of development and reproductive performance of mice from the Swiss strain.

\section{Conclusions}

Based on these results, it is possible to conclude that the use of tubular devices as a factor of enrichment of micro-environments of outbred mice of the Swiss strain does not affect significantly their development and reproductive performance.

\section{References}

BOEHM, GW., SHERMAN, GF., HOPLIGHT, BJ., HYDE, LA., WATERS, NS., BRADWAY, DM., GULABURDA, AM. and DENENBERG, VH., 1996. Learning and memory in the autoimmune BXSB mouse: effects of neocortical ectopias and environmental enrichment. Brain Research, vol. 726, no. 1-2, p. 11-22.

BROOM, DM. and JOHNSON, KG., 1993. Stress and animal welfare. London: Chapman and Hall. 228p.

FORGAYS, DG. and FORGAYS, JW., 1952. The nature of the effect of free-environmental experience in the rat. Journal of Comparative Physiology and Psychology, vol. 45, no. 4, p. $322-328$

GONYOU, HW., 1986. Assessment of comfort and wellbeing in farm animals. Journal of Animal Science, vol. 62, p. $1769-1775$.

HEBB, DO., 1947. The effects of early experience on problem solving at maturity. American Psychologist, vol. 2, no. 2, p. 306-307.

HULS, WL., BROOKS, DL. and BEAN-KNUDSEN, D., 1991. Response of adult New Zealand White rabbits to enrichment objects and paired housing. Laboratory Animal Science, vol. 41, no. 6, p. 609-612.

INGLIS, CA., CAMPBELL, ER., AUCIELLO, SL. and SARAWAR, SR., 2004. Effects of enrichment devices on stressrelated problems in mouse breeding. San Diego: Torrey Pines Institute for Molecular Studies. Available from: <http://caat. jhsph.edu/programs/AWE/2004/final.htm>. Access in: 30 de Julho de 2006.

ITURRIAN, WB. and FINK, GB., 1968. Comparison of bedding material: habitat preference of pregnant mice and reproductive performance. Laboratory Animal Care, vol. 18, no. 2 , p. $160-164$.

JENSEN, PF. and TOATES, M., 1993. Who needs 'behavioural needs'?: motivational aspects of the needs of animals. Applied Animal Behaviour Science, vol. 37, p. 161-181.

MANOSEVITZ, M., 1970. Early environmental enrichment and mouse behavior. Journal of Comparative Physiology and Psychology, vol. 71, no. 3, p. 459-466.

MANOSEVITZ, M. and MONTEMAYOR, RJ., 1972. Interaction of environmental enrichment and genotype. Journal 
of Comparative Physiology and Psychology, vol. 79, no. 1, p. 67-76.

MARASHI, V., BARNEKOW, A., OSSENDORF, E. and SACHSER, N., 2003. Effects of different form of environmental enrichment on behavioral, endocrinological, and immunological paramenters in male mice. Hormones and Behavior, vol. 43, no. 2, p. 281-292.

MARASHI, V., BARNEKOW, A. and SACHSER, N., 2004. Effects of environmental enrichment on males of a docile inbred strain of mice. Physiology and Behavior, vol. 82, no. 5, p. 765-776.

MENCH, JA., 1994. Environmental enrichment and exploration. Laboratory Animals, vol. 23, no. 2, p. 38-41.

MIRONE, L., PANZERELLA, FP. and CERECEDO, LR., 1948. A new method of reporting data on reproduction and lactation in the mouse. Science, vol. 108, no. 2797, p. 139-140.

POTGIETER, FJ. and WILKE, PI., 1997. Effect of different bedding materials on the reproductive performance of mice. Journal of the South African Veterinary Association, vol. 68, no. 1 , p. 8-15.

PRIOR, H. and SACHSER, N., 1995. Effects of enriched housing environment on the behaviour of young male and female mice in four exploratory tasks. Journal of Experimental Animal Science, vol. 37, p. 57-68.

RENNER, MJ. and ROSENZWEIG, MR., 1986. Object interactions in juvenile rats (Rattus norvegicus): effects of different experiential histories. Journal of Comparative Psychology, vol. 100, no. 3, p. 229-236.
RÖTTGER, C., MARASHI, V. and SACHSER, N., 2001. Effects of environmental enrichment on anxiety, exploratory behaviour, locomotor activity, and learning in male mice of the inbred strain AB/Gat. Zoology, vol. 104, suppl. IV, p. 8.

SACHSER, N., DÜRSCHLAG, M. and HIRZEL, D., 1998. Social relationships and the management of stress. Psychoneuroendocrinology, vol. 23, no. 8, p. 891-904.

UNIVERSITIES FEDERATION FOR ANIMAL WELFARE UFAW. The UFAW handbook on the care and management of laboratory animals. London; New York: Churchill Livingstone, 1986. 635p.

VAN de WEERD, HA., VAN LOO, PLP. and BAUMANS, V. 2004. Environmental enrichment: room for reduction. Alternatives to Laboratory Animals, vol. 32, suppl. 2, p. 69-71.

VAN de WEERD, HA., VAN LOO, PLP., VAN ZUTPHEN, LFM., KOOLHAAS, JM. and BAUMANS, V., 1998. Strength of preference for nesting material as environmental enrichment for laboratory mice. Applied Animal Behaviour Science, vol. 55, no. 3-4, p. 369-382.

VAN LOO, PLP., MOL, JA., KOOLHAAS, JM., VAN ZUTPHEN, BFM. and BAUMANS, V., 2001. Modulation of aggression in male mice: influence of group size and cage size. Physiology and Behavior, vol. 72, no. 5, p. 675-683.

VON HOLST, D., 1998. The concept of stress and its relevance for animal behavior. Advances in the Study of Behavior, vol. 27, p. 1-131.

WIDMAN, DR. and ROSELLINI, RA., 1990. Restricted daily exposure to environmental enrichment increases the diversity of exploration. Physiology and Behavior, vol. 47, no. 1, p. 57-62. 